\title{
Presence of anti-Leishmania spp. antibodies in slaughter horses in Brazil
}

\section{Presença de anticorpos anti-Leishmania spp. em cavalos de abate no Brasil}

\author{
Fernanda Evers $^{1 *}$; Fernanda Pinto Ferreira ${ }^{1}$; Italmar Teodorico Navarro ${ }^{2}$; \\ Regina Mitsuka-Breganó ${ }^{2}$; Sthefany Pagliari ${ }^{1}$; Thais Cabral Monica ${ }^{1}$; \\ Beatriz de Souza Lima Nino ${ }^{1}$; Roberta Lemos Freire ${ }^{2}$
}

\begin{abstract}
The objective of this study was to investigate the presence of anti-Leishmania spp. antibodies using an indirect immunofluorescence technique in the serum of equidae slaughtered in two slaughterhouses registered with the Federal Inspection Service. Titers greater than 40 were considered reagents. Blood samples were collected from 398 animals of both sexes, with different ages, and coming from six Brazilian states, of which $46.0 \%$ (183/398) were reactive, indicating that these animals were exposed to the leishmaniasis agent that is widely distributed in Brazil.
\end{abstract}

Key words: Slaughterhouse. Equine. Leishmaniosis. IFAT. Serology.

\section{Resumo}

O objetivo deste estudo foi investigar a presença de anticorpos anti-Leishmania spp. utilizando a técnica de imunofluorescência indireta em amostras de soro de equídeos abatidos em dois matadouros registrados no Serviço de Inspeção Federal. Os títulos superiores a 40 foram considerados reagentes. Foram coletadas amostras de sangue de 398 animais de ambos os sexos, com diferentes idades e provenientes de seis estados brasileiros, dos quais 46,0\% (183/398) foram reativos, indicando que esses animais foram expostos ao agente de leishmaniose, amplamente distribuído no Brasil.

Palavras-chave: Matadouro. Equinos. Leishmaniose. RIFI. Sorologia.

\footnotetext{
${ }^{1}$ Discentes, Universidade Estadual de Londrina, UEL, Londrina, PR, Brasil. E-mail: fervet.76@hotmail.com; nandaferreiravet@gmail.com; sthefanypagliari@gmail.com; thaismonicavet@gmail.com; bianino@hotmail.com

2 Profs. Drs., Departamento de Medicina Veterinária Preventiva, UEL, Londrina, PR, Brasil. E-mail: italmar@uel.br; rbregano@ gmail.com; rlfreire@uel.br

* Author for correspondence
} 
In Brazil, equidae breeding is not an economic activity focused on slaughter. The production of this meat comes from animals that have been removed from work or reproduction, and are only destined for export, since the consumption of meat in the country is uncommon (TORRES; JARDIM, 1987). These animals often have longer lives and consequently prolonged contact with the environment, increasing the possibility of infection with some organisms, such as Leishmania spp.

Leishmaniasis is present in all continents, with the exception of Antarctica and Australia; however, it is considered a neglected disease and is of great importance in public health (ALVAR et al., 2012). Equidae, as traction animals, are in constant movement in endemic areas, serving as food sources of phlebotomine and allowing for population growth, and consequently, maintenance of the peridomestic cycle (CERQUEIRA et al., 2003; TRUPPEL et al., 2014). Although they can infect themselves with leishmaniasis, the role of this animal in the transmission chain of leishmaniasis has not been elucidated (KOUAM et al., 2010).

Studying antibodies against Leishmania spp. in horses may reveal what occurs in the human environment, because they can share the same space in rural or urban areas. The aim of this study was to investigate the presence of antibodies against Leishmania spp. using serology in slaughtered horses.

Samples were obtained from equines from randomly chosen batches slaughtered at two meat factories licensed by the Federal Inspection Service in the state of Paraná. The sample size was calculated using the Epi Info 6.04 software (DEAN et al., 1990), considering a target population of around 4000 animals, with an estimated prevalence of $50 \%$, error of $5 \%$, and significance level of $5 \%$, totaling 384 animals. The study was approved by the Ethics Committee on Animal Experimentation of the State University of Londrina, Paraná ( $\left.\mathrm{N}^{\circ} 60 / 09\right)$.
Between July 2009 and January 2010, we studied 398 adult equids of different ages and both sexes from the following Brazilian states and cities: Paraná ( $\mathrm{n}=153)$ - Apucarana (4), Araruna (4), Borrazópolis (4), Cafezal do Sul (15), Campina Grande do Sul (27), Imbituva (13), Londrina (3), Lobato (33), Marquinho (12), Novo Itacolomi (7), Prudentópolis (12), Ribeirão Claro (9), Rio Bom (2), São João do Ivaí (3), and Santa Fé (4); Minas Gerais ( $n=53)$ - Frutal (33) and Itapagipe (20); Rio de Janeiro ( $n=39)$ - Italva (39); Goiás $(n=6)$ Caiapônia (6); Mato Grosso do Sul (n=99) - Coronel Sapucaia (10), Deodápolis (21), Paranaíba (22), and Rio Verde de Mato Grosso (46); and Mato Grosso $(n=49)$ - Cáceres (20), Canarana (12), Cuiabá (17).

Ten milliliters of blood was collected; after clot retraction, the serum was placed in $1.5-\mathrm{mL}$ polyethylene tubes and was stored at $-15^{\circ} \mathrm{C}$ until serological tests were performed in the Zoonosis and Public Health Laboratories of the State University of Londrina.

The presence of IgG anti-Leishmania spp. antibodies was investigated using the indirect fluorescent antibody test (IFAT) (OLIVEIRA et al., 2008). Commercials Slides (Imunodot, São Paulo, Brazil) containing promastigote forms of Leishmania chagasi were used. Conjugated antiequine IgG (Sigma, Missouri, USA) and positive and negative sera controls were added to each slide. Dilutions ${ }^{3}$ 1:40 were considered positive. The positive controls for Leishmania spp. were obtained from naturally infected animals. The choice of antigen was based on the presence of the agent in most of the studied states, besides the fact that there was a cross-reaction between trypanosomatids (SUNDAR; RAI, 2002).

Prevalence rates were calculated for the etiologic agent. The associations between the results obtained were evaluated with the chi-square test, performed using Epi Info 6.04 (DEAN et al., 1990). We established a significance level of $5 \%$. 
Out of the 398 serum samples subjected to antiLeishmania spp. antibody investigation through the IFAT, 183 (46.0\%; 95\% CI $=41.0-51.0)$ were positive. When observed by region, $48.0 \%(73 / 152)$ were from the South, 39.1\% (36/92) from the Southeast, and 48.1\% (74/154) from the centerwest regions, as detailed in Table 1 and Figure 1. There was no significant difference between the regions in the study. The results demonstrated that leishmaniasis is widely disseminated in the animal's home environment. The role of equids in the cycle of leishmaniasis has not yet been fully elucidated (TRUPPEL et al., 2014); however, these animals can act as sentinels and participate in the transmission chain (BRASIL, 2007). Villalobos et al. (2010) demonstrated similar prevalence rates in research carried out in the region of Bauru, São Paulo; the Southeast region revealed $40.0 \%$ positivity among the 100 horses examined using the IFAT.

Table 1. Results of Indirect Fluorescent Antibody Test for Leishmania spp in 398 horses from slaughterhouse in Paraná State, Brazil, according to the region, 2009-2010.

\begin{tabular}{|c|c|c|c|c|}
\hline Region & State & Municipality & Positive & TOTAL \\
\hline \multirow{15}{*}{ SOUTH } & PR & Araruna & 4 & 4 \\
\hline & PR & Apucarana & 1 & 4 \\
\hline & PR & Borrazópolis & 1 & 4 \\
\hline & PR & Cafezal do Sul & 9 & 15 \\
\hline & PR & Campina Grande do Sul & 8 & 27 \\
\hline & PR & Imbituva & 4 & 13 \\
\hline & PR & Lobato & 20 & 33 \\
\hline & PR & Londrina & 1 & 3 \\
\hline & PR & Marquinho & 4 & 12 \\
\hline & PR & Novo Itacolomi & 5 & 7 \\
\hline & PR & Prudentópolis & 8 & 12 \\
\hline & PR & Ribeirao Claro & 6 & 9 \\
\hline & PR & Rio Bom & 2 & 2 \\
\hline & PR & Santa Fé & 0 & 4 \\
\hline & PR & São José do Ivaí & 0 & 3 \\
\hline Total $(\%)$ & & & 73 & $152(38,2)$ \\
\hline \multirow{3}{*}{ SOUTHEAST } & MG & Itapagipe & 11 & 20 \\
\hline & MG & Frutal & 11 & 33 \\
\hline & $\mathrm{RJ}$ & Italva & 14 & 39 \\
\hline Total $(\%)$ & & & 36 & $92(23,1)$ \\
\hline \multirow{8}{*}{ CENTER-WEST } & GO & Caiapônia & 5 & 6 \\
\hline & MS & Coronel Sapucaia & 5 & 10 \\
\hline & MS & Deodápolis & 8 & 21 \\
\hline & MS & Paranaíba & 16 & 22 \\
\hline & MT & Cáceres & 10 & 20 \\
\hline & MT & Canarana & 5 & 12 \\
\hline & MT & Cuiabá & 7 & 17 \\
\hline & MT & Rio Verde de Mato Grosso & 18 & 46 \\
\hline Total (\%) & & & 74 & $154(38,7)$ \\
\hline TOTAL (\%) & & & 183 & $398(46,0)$ \\
\hline
\end{tabular}

IFAT* Indirect fluorescence antibody test, cut-off $\geq 40$ Positive results

$\mathrm{PR}=$ Paraná; $\mathrm{RJ}=$ Rio de Janeiro; $\mathrm{MG}=$ Minas Gerais; $\mathrm{GO}=$ Goiás;

$\mathrm{MS}=$ Mato Grosso do Sul; MT= Mato Grosso. 
In the present study, Paraná revealed a frequency of $48.0 \%(73 / 152)$, less than that obtained by Vedovello Filho et al. (2008), who investigated Leishmania spp. in 55 equines from endemic areas in Paraná and obtained 42 positive results $(76.3 \%)$, using the direct agglutination test (DAT). In 3 of these (7.1\%), genetic material of Leishmania (Viannia) was detected. Because these originated from an outbreak, the results suggest that these equines were participating in the cycle of the disease, as well as in the process of urbanization of ACL. Truppel et al. (2014), to evaluate the role of horses in the
Leishmania cycle, analyzed blood samples from 227 animals from the northern region of Paraná, Brazil, using the enzyme-linked immunosorbent assay (ELISA) and polymerase chain reaction (PCR) methods. The results indicated that $11.0 \%$ $(25 / 227)$ of the horses were sero-positive and $16.3 \%$ (37/227) were PCR-positive for Leishmania braziliensis, indicating that these animals could serve as food sources of phlebotomine outside the home and, consequently, play a role in the cutaneous leishmaniasis cycle.

Figure 1. Positive results for Leishmania spp. in horses from slaughterhouses in Paraná State, Brazil, according to the region of origin, 2009- 2010.

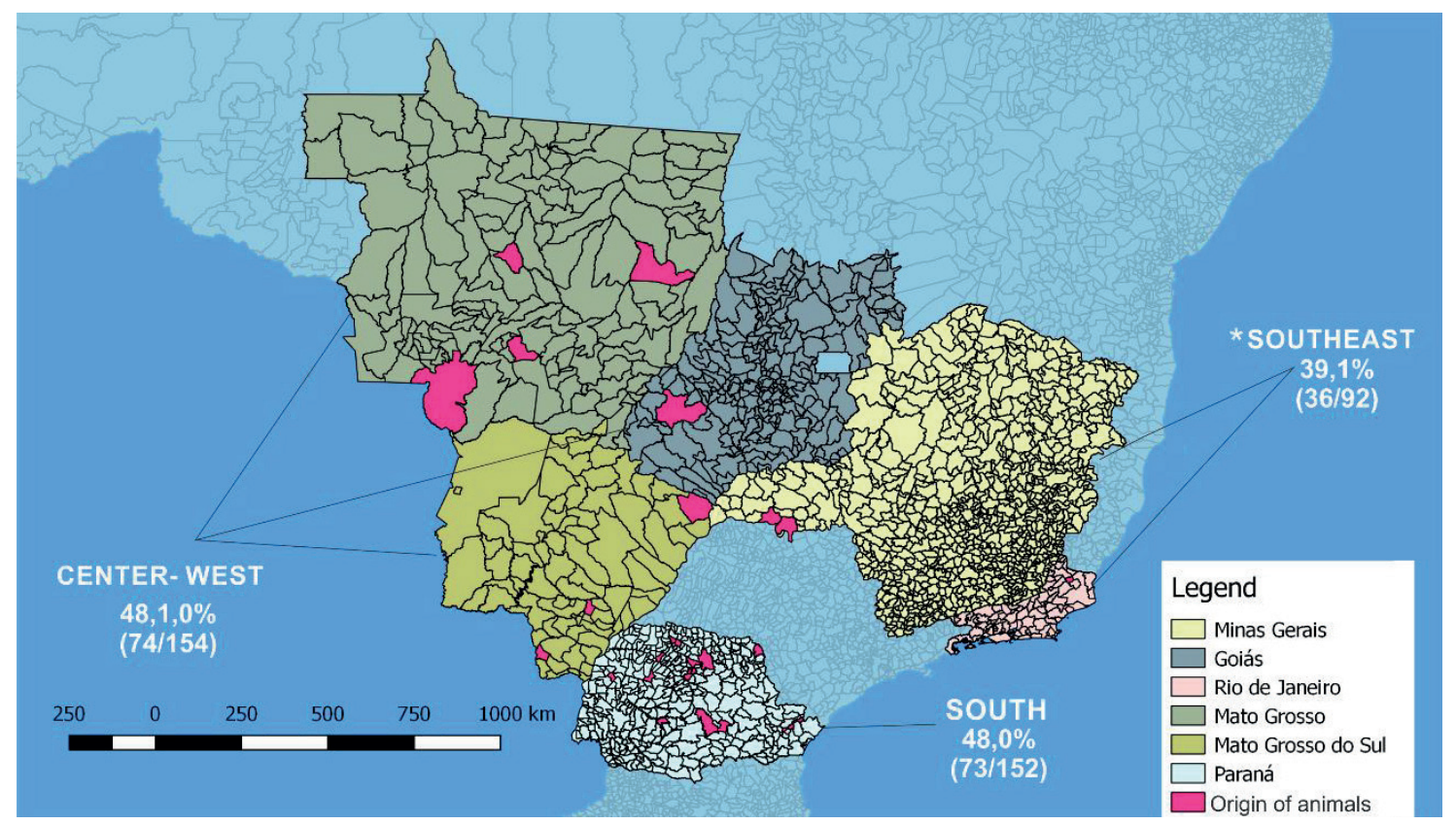

In a study conducted in rural communities in four municipalities in the Ribeira valley between 1993 and 2003, Castro et al. (2005) did not suggest any indications that the horses examined were a reservoir for $L$. (V.) braziliensis. Among these horses, only four of them revealed cutaneous lesions compatible with ACL, and these were demonstrated to be negative upon isolation and in the anatomopathological examination. Regarding visceral leishmaniasis, Cerqueira et al. (2003) inoculated four Equus asinus with Leishmania chagasi promastigotes; these were followed up for 12 months, and although they were challenged with a high number of promastigotes, the animals did not develop apparent infections and were not experimentally infected with the vector Lutzomyia longipalpis. The horse is one of the animals of choice as a food preference for sand flies (OLIVEIRA-PEREIRA et al., 2008), and thus significantly contributes to the maintenance of the vectors in the environment. 
The results of this study are different to those suggested by Soares et al. (2013), who performed the IFAT in 210 horses originating from the city of Belo Horizonte, Minas Gerais, and 65.20\% (137/210) presented with anti-Leishmania spp. antibodies. Oliveira et al. (2017) evaluated the occurrence of antibodies against Leishmania spp. in 242 horses from the city of Uberlândia, Minas Gerais, using the same method, and observed a positivity of $22.7 \%$ (55/242). Follador et al. (1999) analyzed 77 equines in rural areas of Santo Amaro, Salvador, Bahia with ELISA, using antigens of $L$. brasiliensis and obtained 17 (22\%) sero-positive animals. The results were lower than those found in the species analyzed in this work.

Degradation of the native forest, high humidity, introduction of new crops and monocultures, and the density and availability of organic matter for sandflies in peridomestic areas and in animal shelters appear to be risk factors for infection, as well as activities relating to soil cultivation and access of animals to riverbanks (YOSHIDA et al., 1990; FOLLADOR et al., 1999; VEDOVELLO FILHO et al., 2008).

The elevated sero-prevalence of antibodies against Leishmania spp. in horses in the studied regions suggest that these animals were exposed to the pathogen, and the environment shared with humans presented a risk of infection by the agent.

\section{References}

ALVAR, J.; VELEZ, I. D.; BERN, C.; HERRERO, M.; DESJEUX, P.; CANO, J.; JANNIN, J.; BOER, M.; WHO Leishmaniasis Control Team. Leishmaniasis worldwide and global estimates of its incidence. PloS One, California, v. 177, n. 5, e35671, p. 1-12, 2012.

BRASIL. Ministério da Saúde. Manual de vigilância da Leishmaniose Tegumentar Americana. 2. ed. Brasília: Ministério da Saúde, 2007. 180 p.

CASTRO, E. A.; LUZ, E.; TELLES, F. Q.; PANDEY, A.; BISETO, A.; DINAISKI, M.; SBALQUEIRO, I.; SOCCOL, V. T. Eco-epidemiological survey of Leishmania (Viannia) braziliensis American cutaneous and mucocutaneous leishmaniasis in Ribeira Valley River, Paraná State, Brazil. Acta Tropica, Amsterdam, v. 93, n. 2, p. 141-149, 2005.

CERQUEIRA, E. J. L.; SHERLOCK, I.; GUSMÃO, A.; BARBOSA JUNIOR, A. A.; NAKATANI, M. Inoculação experimental de Equus asinus com Leishmania chagasi Cunha \& Chagas, 1937. Revista da Sociedade Brasileira de Medicina Tropical, Uberaba, v. 36, n. 6, p. 695-701, 2003.

DEAN, A. G.; DEAN, J. A.; BURTON, A. H.; DICKER, R. C. Epi info: a general-purpose microcomputer program for public health information systems. American Journal of Preventive Medicine, Amsterdam, v. 7, n. 3, p. 178182, 1990.

FOLLADOR, I.; ARAUJO, C.; CARDOSO, M. A.; TAVARES-NETO, J.; BARRAL, A.; MIRANDA, J. C.; BITTENCOURT, A.; CARVALHO, E. M. Surto de leishmaniose tegumentar americana em Canoa, Santo Amaro, Bahia, Brasil. Revista da Sociedade Brasileira de Medicina Tropical, Uberaba, v. 32, n. 5, p. 497-503, 1999.

KOUAM, M. K.; DIAKOU, A.; KANZOURA, V.; PAPADOPOULOS, E.; GAJADHAR, A. A.; THEODOROPOULOS, G. A seroepidemiological study of exposure to Toxoplasma, Leishmania, Echinococcus and Trichinella in equids in Greece and analysis of risk factors. Veterinary Parasitology, Amsterdam, v. 170, n. 1, p. 170-175, 2010.

OLIVEIRA, P. M.; GARCIA, F.; EVERS, F.; BARBOSA, V. M.; OBANDO, D. C. M.; NASCIUTTI, N. R.; GARCIA, J. L.; NOGUEIRA, G. M.; HEADLEY, S. A.; SAUT, J. P. E. Seroepidemiology of Leishmania spp. in equids from Uberlândia, Minas Gerais, Brazil. Ciência Rural, Santa Maria, v. 47, n. 5, p 1-4, 2017.

OLIVEIRA, T. M. F. S; FURUTA, P. I.; CARVALHO, D.; MACHADO, R. Z. A study of cross-reactivity in serum samples from dogs positive for Leishmania $s p$., Babesia canis and Ehrlichia canis in enzyme-linked immunosorbent assay and indirect fluorescent antibody test. Revista Brasileira de Parasitologia Veterinária, Jaboticabal, v. 17, n. 1, p. 7-11, 2008.

OLIVEIRA-PEREIRA, Y. N.; MORAES, J. L. P.; LOROSA, E. S.; REBÊLO, J. M. M. Preferência alimentar sanguínea de flebotomíneos da Amazônia do Maranhão, Brasil. Caderno de Saúde Pública, Rio de Janeiro, v. 24, n. 9, p. 2183-2186, 2008.

SOARES, I. R.; SILVA, S. O.; MOREIRA, F. M.; PRADO, L. G.; FANTINI, P.; MARANHÃO, R.D.P.A.; SILVA FILHO, J. M.; MELO, M. N.; PALHARES, M. S. First evidence of autochthonous cases of Leishmania 
(Leishmania) infantum in horse (Equus caballus) in the Americas and mixed infection of Leishmania infantum and Leishmania (Viannia) braziliensis. Veterinary Parasitology, Amsterdam, v. 197, n. 3-4, p. 665-669, 2013.

SUNDAR, S.; RAI, M. Laboratory diagnosis of visceral leishmaniasis. Clinical and Diagnostic Laboratory Immunology, Bethesda, v. 9, n. 5, p. 951-958, 2002.

TORRES, A. P.; JARDIM, W. R. Criação de cavalos e outros equídeos. 3. ed. São Paulo: Nobel, 1987. 654 p.

TRUPPEL, J. H.; OTOMURA, F.; TEODORO, U.; MASSAFERA, R.; COSTA-RIBEIRO, M. C. V.; CATARINO, C. M.; DALAGRANA, L.; FERREIRA, M. E. M. C.; THOMAZ-SOCCOL, V. Can equids be a reservoir of Leishmania braziliensis in endemic areas? PlosOne, California, v. 9, n. 4, e93731, p. 1-6, 2014.
VEDOVELLOFILHO, D.; JORGE, F. A.; LONARDONI, M. V. C.; TEODORO, U.; SILVEIRA, T. G. V. American cutaneous leishmaniasis in horses from endemic areas in thenorth-central mesoregion of Paraná state, Brazil. Zoonoses and Public Health, Medford, v. 55, n. 3, p. 149155, 2008.

VILLALOBOS, E. M. C.; CARVALHO, P. R.; LARA, M. C. C. S. H.; MARQUES, E. C.; SOUZA, M. C. A. M.; FELICIO, P. S.; CUNHA, M. S.; CUNHA, E. M. S. Prevalence of immune response of healthy equines with antibodies anti Leishmania chagasi in an endemic area of leishmaniasis. Middle East Journal of Scientific Resear Research, v. 5, n. 6, p. 520-534, 2010.

YOSHIDA, E. L.; CORREA, F. M.; MARQUES, S. A.; STOLF, H. O.; DILlON, N. L.; MOMEN, H.; GRIMALDI, G. Human, canine and equine (Equus caballus) leishmaniasis due to Leishmania braziliensis (L. braziliensis braziliensis) in the south-west region of São Paulo State, Brazil. Memórias do Instituto Oswaldo Cruz, Rio de Janeiro, v. 85, n. 1, p. 133-134, 1990. 